\title{
Differential Effects of Metalloporphyrins on Messenger RNA Levels of $\delta$-Aminolevulinate Synthase and Heme Oxygenase Studies in Cultured Chick Embryo Liver Cells
}

\author{
Edward E. Cable, ${ }^{\star \star}$ Joyce A. Pepe, ${ }^{\star \star 5}$ Nicholas C. Karamitsios, ${ }^{\star}$ Richard W. Lambrecht, ${ }^{\star \S}$ and Herbert L. Bonkovsky ${ }^{\star \star \$}$ \\ Departments of ${ }^{*}$ Medicine, ${ }^{\ddagger}$ Biochemistry and Molecular Biology, and ${ }^{\S}$ The Center for Study of Disorders of Iron and Porphyrin \\ Metabolism, University of Massachusetts Medical Center, Worcester, Massachusetts 01655
}

\begin{abstract}
The acute porphyrias in relapse are commonly treated with intravenous heme infusion to decrease the activity of $\delta$ aminolevulinic acid synthase, normally the rate-controlling enzyme in heme biosynthesis. The biochemical effects of heme treatment are short-lived, probably due in part to heme-mediated induction of heme oxygenase, the rate-controlling enzyme for heme degradation. In this work, selected nonheme metalloporphyrins were screened for their ability to reduce $\delta$-aminolevulinic acid synthase mRNA and induce heme oxygenase mRNA in chick embryo liver cell cultures. Of the metalloporphyrins tested, only zinc-mesoporphyrin reduced $\delta$-aminolevulinic acid synthase mRNA without increasing heme oxygenase mRNA. The combination of zincmesoporphyrin and heme, at nanomolar concentrations, decreased $\delta$-aminolevulinic acid synthase mRNA in a dosedependent manner. The combination of zinc-mesoporphyrin (50 $\mathrm{nM})$ and heme (200 $\mathrm{nM})$ decreased the half-life of the mRNA for $\delta$-aminolevulinic acid synthase from 5.2 to $\mathbf{2 . 5}$ $h$, while a similar decrease was produced by heme $(10 \mu \mathrm{M})$ alone $(2.2 \mathrm{~h})$. The ability of zinc-mesoporphyrin to supplement the reduction of $\delta$-aminolevulinic acid synthase mRNA by heme, in a process similar to that observed with heme alone, provides a rationale for further investigation of this compound for eventual use as a supplement to heme therapy of the acute porphyrias and perhaps other conditions in which heme may be of benefit. (J. Clin. Invest. 1994. 94:649654.) Key words: $\delta$-aminolevulinic acid synthetase $\bullet$ heme $\bullet$ heme oxygenase $\bullet$ metalloporphyrins $\bullet$ RNA, messenger
\end{abstract}

\section{Introduction}

Acute intermittent porphyria (AIP) ${ }^{1}$ the most common form of the acute hepatic porphyrias (1-3), is due to an autosomal

Address correspondence to Herbert L. Bonkovsky, M.D., Division of Digestive Disease, University of Massachusetts Medical Center, Worcester, MA 01655. 1994.

Received for publication 1 October 1993 and in revised form 1 April

1. Abbreviations used in this paper: AIP, acute intermittent porphyria; ALA, $\delta$-aminolevulinate; CoP, cobalt protoporphyrin IX; CrM, chromium mesoporphyrin IX; HO, heme oxygenase; MePn, metalloporphyrin; MnP, manganese-protoporphyrin IX; NiM, nickel mesoporphyrin IX; PBG, porphobilinogen; poly-T, poly-thymidylate; SnM, tin-mesoporphyrin IX; SnP, tin-protoporphyrin IX; ZnM, zinc-mesoporphyrin IX.

J. Clin. Invest.

(c) The American Society for Clinical Investigation, Inc. 0021-9738/94/08/0649/06 \$2.00

Volume 94, August 1994, 649-654 dominantly inherited defect in porphobilinogen (PBG) deaminase. During the acute phase of AIP, urinary excretions of $\delta$ aminolevulinic acid (ALA) and PBG increase 20-200-fold, and excretions of uroporphyrin and coproporphyrin are also increased (1). Other acute hepatic porphyrias include hereditary coproporphyria and variegate porphyria (4). The biochemical feature common to all acute porphyrias in relapse is an uncontrolled induction of ALA synthase (E.C. 2.3.1.37), the first and normally rate-controlling enzyme in heme biosynthesis (1-3). The treatment of choice, for all but mild attacks of acute porphyria, is intravenous heme (5-8), first described 23 yr ago (8). Heme reduces hepatic ALA synthase levels in various experimental models of acute porphyria (9-12) and apparently has the same effect in patients suffering from acute porphyria (58). The mechanism(s) whereby heme exerts a repressive effect on hepatic ALA synthase may be manifold, including decreasing mRNA stability $(13,14)$ and decreasing import of the enzyme into mitochondria $(15,16)$.

Metalloporphyrins which inhibit heme oxygenase (HO) (E.C. 1.14.88.3) were first suggested as a possible treatment for acute porphyrias in studies with rats pretreated with allylisopropylacetamide, a potent experimental porphyrogen, and subsequently treated with tin-protoporphyrin (SnP) (17). (SnP has also been used to decrease bilirubin production in neonates and in experimental jaundice $[18,19]$.) Tin-mesoporphyrin (SnM) was later found to be a more potent inhibitor of HO activity than SnP and to be chemically more stable (20). Tin-diiododeuteroporphyrin has also been tested for its ability to inhibit $\mathrm{HO}$ and to produce photosensitivity (21).

Concerns regarding the clinical use of tin-porphyrins as inhibitors of $\mathrm{HO}$ include their propensity to produce phototoxicity and sensitivity $(22,23)$, their long biologic half-lives, their ability to cross the blood-brain barrier (24), and the possible toxicity of tin itself, if it were to be released from the porphyrin macrocycle (for review see reference 3 ). In addition, tin- or cobalt-metalloporphyrins that inhibit HO have been found to induce expression of the $\mathrm{HO}$ gene $(25,26)$.

The ideal metalloporphyrin (MePn) for eventual clinical use in the treatment of porphyria should reduce ALA synthase activities and mRNA levels without causing photosensitivity or other toxicity and without exerting other unwanted effects, such as induction of $\mathrm{HO} \mathrm{mRNA}$ and protein levels. Zinc-containing MePns are of interest in this regard since they inhibit HO (27$30)$, cause little or no phototoxicity $(30,31)$, and do not cross the blood-brain barrier (24). In addition, zinc is an essential trace metal, and normal human erythrocytes (and perhaps other cells as well) contain zinc protoporphyrin $(32,33)$.

Primary chick embryo liver cell cultures are a simple, reproducible system for studying hepatic porphyrin metabolism and its regulation $(9,12,15,30,34-37)$. The kinetics of the conversion of ALA to heme in human liver resembles that of chicks 
more closely than that of rats $(38,39)$. Heme-albumin solutions have been effective in cultured cells and humans at reducing ALA synthase activity $(9,12,30,36)$ and excretions of ALA and PBG $(1-3,5-8,40)$. We have used the chick embryo liver culture system to test various MePn-albumin complexes for effects on heme metabolism $(30,41)$.

An important recent finding was that zinc-mesoporphyrin $(\mathrm{ZnM})(50 \mathrm{nM})$ significantly reduced the high ALA synthase activities in cultured chick embryo liver cells treated with glutethimide and iron (30) or glutethimide and 4,6-dioxoheptanoic acid, an inhibitor of heme synthesis (41). Furthermore, low concentrations of $\mathrm{ZnM}$ enhanced the effectiveness of nanomolar concentrations of heme to reduce ALA synthase activities in a dose-dependent manner, showing for the first time that the combination of an MePn inhibitory for $\mathrm{HO}$ and heme was capable of additively repressing ALA synthase activity, in addition to prolonging the heme-dependent reduction of ALA synthase activity $(23,42)$.

We show in this work that several MePns that inhibit HO decrease ALA synthase mRNA levels, in chick embryo liver cells pretreated with glutethimide and iron, a pretreatment that markedly increases ALA synthase activity and mRNA levels $(30,36)$ as well as activity and mRNA of HO (37). In these cultures, ZnM effectively reduced ALA synthase mRNA and, in other cultures not treated with glutethimide and iron, it did not increase levels of mRNA of HO. In contrast, SnM and heme, although equally as effective as $\mathrm{ZnM}$ at reducing ALA synthase mRNA, induced HO mRNA levels when tested in a similar fashion. The time course of HO mRNA induction was quite rapid for both heme and other MePns (SnM and cobaltprotoporphyrin IX [CoP]), and, following SnM or CoP treatment, high levels of $\mathrm{HO}$ mRNA were maintained for at least as long as $18 \mathrm{~h}$. Furthermore, combinations of $\mathrm{ZnM}$ and heme reduced levels of ALA synthase mRNA in a dose-dependent manner at concentrations up to $200 \mathrm{nM}^{2}$ with the effective combinations reducing the half-life of ALA synthase mRNA.

\section{Methods}

Materials. All tissue culture dishes were from Corning Glass Inc. (Corning, NY). Chloroform, dimethylformamide, and isopropanol were from Fisher (Pittsburgh, PA). Dexamethasone was from Gensia Pharmaceuticals (Irvine, $\mathrm{CA})$. pd(N) ${ }_{6}$ and Oligo $\mathrm{dT}_{(12-18)}$ were from Pharmacia LKB Biotechnology Inc. (Piscataway, NJ). Cobalt $\left(\mathrm{Co}^{+3}\right)$-protoporphyrin $\mathrm{IX} \cdot \mathrm{Cl}$, chromium $\left(\mathrm{Cr}^{+3}\right)$-mesoporphyrin $\mathrm{IX} \cdot \mathrm{Cl}$, ferric $\left(\mathrm{Fe}^{+3}\right)$-protoporphyrin IX $\cdot \mathbf{C l}\left(\right.$ Hemin), manganese $\left(\mathrm{Mn}^{+3}\right)$-protoporphyrin $\mathrm{IX} \cdot \mathrm{Cl}$, nickel $\left(\mathrm{Ni}^{+2}\right)$-mesoporphyrin IX, protoporphyrin IX, tin $\left(\mathrm{Sn}^{+4}\right)$-mesoporphyrin $\mathrm{IX} \cdot 2 \mathrm{Cl}$, and zinc $\left(\mathrm{Zn}^{+2}\right)$-mesoporphyrin IX were from Porphyrin Products (Logan, UT). All MePns were tested for purity at Porphyrin Products by thin layer chromatography and all were $>97 \%$ pure. In addition, the absorption spectra in pyridine were identical to those observed with the corresponding methyl esters (reference 43 and J. Bommer, personal communication). The MePns were stored in a desiccator at $-20^{\circ} \mathrm{C}$, and, when used, the crystals were dry and free flowing. The plasmid pALX (44) was a generous gift from J. D. Engel (Northwestern University, Evanston, IL). AMV-Reverse Transcriptase, dTTP, Klenow DNA polymerase, and RNAsin were from Promega Corp. (Madison, WI). Actinomycin D, ammonium chloride, diethylpyrocarbonate, DMSO, formaldehyde (37\%), formamide, D-(+)-glucose (tissue culture grade), glutethi-

2. All stated concentrations represent the concentrations in the culture medium. mide, penicillin/streptomycin, polyadenylic acid, salmon sperm DNA, sodium chloride, sodium citrate, sodium dodecyl sulfate, sodium hydroxide, 3,4,3' triiodo-L-thyronine, trizma base, and trypsin were from Sigma Chemical Co. (St. Louis, MO). Fertilized Barred Rock chicken eggs were from Carousel Farms (Hopkinton, MA). Williams' E medium was from GIBCO BRL (Grand Island, NY). Ultraspec RNA was from Biotexc (Houston, TX). Nitrocellulose $(0.45 \mu \mathrm{m})$ was from Schleicher and Schuell, Inc. (Keene, NH). All ${ }^{32} \mathrm{P}$ radionucleotides were from New England Nuclear (Boston, MA).

Methods. Cultures of primary chick embryo liver cells were prepared and chemicals were administered to the cell cultures as described previously $(30,36)$. All MePns were administered as BSA complexes. They were prepared by adding $100 \mu \mathrm{l}$ of $10 \mathrm{mM}$ MePn (dissolved in DMSO) to $3.9 \mathrm{ml}$ of a solution of BSA, $11.1 \mathrm{mg} / \mathrm{ml}$, dissolved in $40 \mathrm{mM}$ Tris$\mathrm{HCl}$ (pH 7.4). The final solutions had a molar ratio of $1.66 \mathrm{~mol} \mathrm{MePn} /$ $1 \mathrm{~mol}$ BSA. The MePn-BSA solutions were prepared under subdued light and immediately added to the cultures. The cultures were incubated in the absence of light.

Total RNA was obtained by harvesting the cells from one $60-\mathrm{mm}$ culture dish directly into $500 \mu \mathrm{l}$ of Ultraspec RNA and isolating the RNA by following the manufacturer's directions. RNA concentrations were estimated by the absorbance at $260 \mathrm{~nm}(1 \mathrm{AU}=40 \mu \mathrm{g} / \mathrm{ml}$ RNA $)$.

Dot-blots were performed on total RNA with a probe that had previously been shown to specifically hybridize with the mRNA of interest under similar hybridization and washing conditions (36, 37, 45, 46). 20 $\mu \mathrm{g}$ of RNA in a final volume of $40 \mu \mathrm{l}$ was treated with $24 \mu \mathrm{l}$ of 20 $\times$ SSC and $16 \mu 1$ of $37 \%$ formaldehyde and incubated at $65^{\circ} \mathrm{C}$ for 15 $\mathrm{min}$. The samples were diluted to $400 \mu \mathrm{l}$ with $10 \times \mathrm{SSC}$ and $10 \mu \mathrm{g}$ of RNA was loaded per dot and duplicate nitrocellulose filters were prepared. The blots were crosslinked by exposure to $2.4 \mu \mathrm{J}$ of UV radiation using a UV-Stratalinker (Stratagene Inc., La Jolla, CA) and prehybridized at $42^{\circ} \mathrm{C}$ in $15 \mathrm{ml}$ of a buffer containing $50 \%$ formamide, $5 \times \mathrm{SSC}$, $100 \mu \mathrm{g} / \mathrm{ml}$ salmon sperm DNA, $5 \times$ Denhardt's, and $1 \%$ SDS. After 1-2 $\mathrm{h}$, the volume of the solution was reduced to 5-7 ml, and a boiled radioactive probe was added to $3.0 \times 10^{7}$ counts per blot. RNA concentrations and loading were normalized for total poly-A mRNA by hybridizing duplicate blots to a poly-thymidylate (poly-T) probe (45, 47). After hybridization for $18 \mathrm{~h}$ at $42^{\circ} \mathrm{C}$, the blots were washed with $0.1 \times \mathrm{SSC}$ at room temperature for $30 \mathrm{~min}$ with two buffer changes and either exposed to $\mathrm{x}$-ray film at $-80^{\circ} \mathrm{C}$ or quantitated on a PhosphorImager (Molecular Dynamics, Sunnyvale, CA). The amount of specific mRNA was normalized to total poly-A mRNA.

All experiments used at least triplicate samples for each treatment condition studied and statistical analyses were done with JMP 2.0 (SAS Institute, Cary, NC) using ANOVA, Tukey-Kramer test for multiple comparisons, or MANOVA as appropriate. $P$ values $<0.05$ were considered significant.

\section{Results}

MePns (10 $\mu \mathrm{M})$ were screened for their ability to reduce ALA synthase mRNA in cell cultures that had been pretreated for 14 h with glutethimide and iron (Fig. $1 A$, abscissa). Previously, this treatment had been shown to induce ALA synthase mRNA to high levels (48). Addition of heme, SnM, or $\mathrm{ZnM}$ for $4 \mathrm{~h}$ was equally effective at reducing ALA synthase mRNA levels, whereas CoP, nickel mesoporphyrin (NiM), and chromium mesoporphyrin (CrM) were less effective, and MnP did not reduce ALA synthase mRNA. These same MePns $(10 \mu \mathrm{M})$ were tested for their ability to induce HO mRNA, in the absence of glutethimide and iron, after treatment for $5 \mathrm{~h}$ (Fig. $1 \mathrm{~A}$, ordinate), a time previously shown to be associated with maximal HO mRNA induction by heme (45). Heme and MnP were the most effective inducers, while potency decreased in the order: $\mathrm{CrM}>\mathrm{CoP}$ $\approx \mathrm{SnM}>\mathrm{ZnM} \approx \mathrm{NiM} \approx \mathrm{No} \mathrm{MePn}$ (ANOVA, $P<0.01$ ). 
$\mathbf{A}$

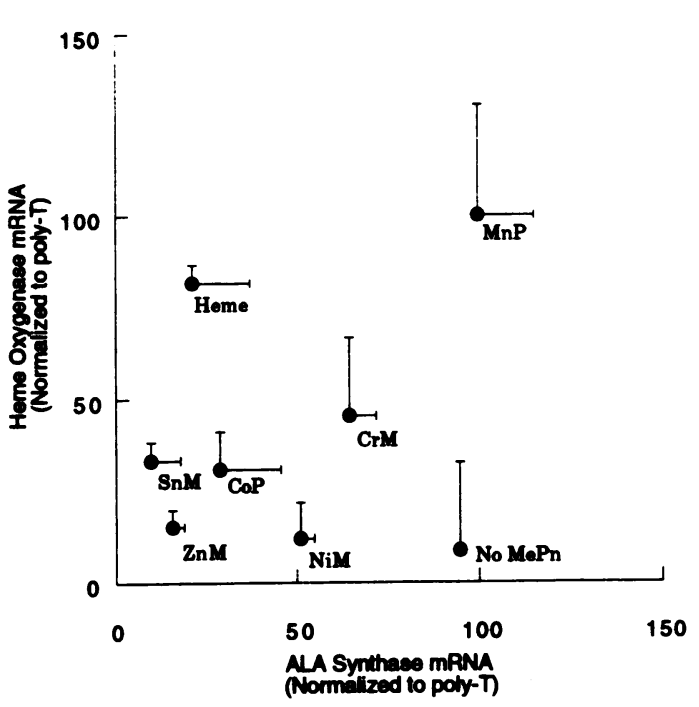

B
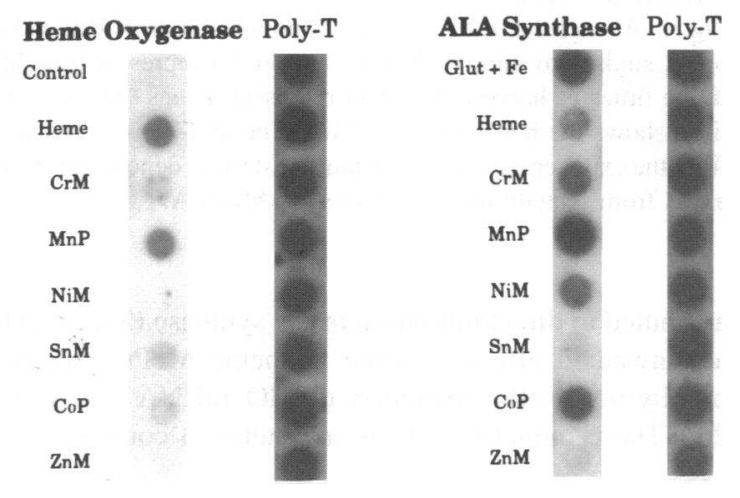

Figure 1. Effects of MePns on ALA synthase and HO mRNA. ALA synthase was induced in chick embryo liver cell cultures by treatment with $50 \mu \mathrm{M}$ glutethimide and $50 \mu \mathrm{M}$ FeNTA for $14 \mathrm{~h}$ before addition of $10 \mu \mathrm{M} \mathrm{MePn}$. The cultures were exposed to the indicated MePn for an additional $4 \mathrm{~h}$ after which they were harvested and mRNA of ALA synthase was measured (abscissa). In separate experiments, mRNA for $\mathrm{HO}$ was measured after treatment of the cultures with $10 \mu \mathrm{M} \mathrm{MePn}$ alone for $5 \mathrm{~h}$ (ordinate). All cultures were harvested and samples prepared and analyzed as described in Methods. Quantitation of dot-blots was done using a PhosphorImager. The relative amounts of specific mRNAs present have been normalized by the amount of poly-T mRNA present in the sample, measured on a duplicate blot. The data represent means+SE, $n=3(A)$, while the blot shows representative individual samples and the corresponding poly-T controls $(B)$. There is no horizontal error bar for no MePn because, for this condition, the error fell within the size of the symbol.

The photograph (Fig. $1 B$ ) shows individual samples and corresponding filters probed for poly-T content.

The time course of induction of HO mRNA demonstrated a rapid and transient increase in the presence of heme, while $\mathrm{CoP}$ and SnM produced a less rapid increase in HO mRNA with levels increasing for at least $9 \mathrm{~h}$ (Fig. 2). Subsequent experiments for longer times indicated that the induction of HO mRNA was the slowest for cobalt, with HO mRNA levels increasing steadily for at least $18 \mathrm{~h}$ (data not shown). Protopor-

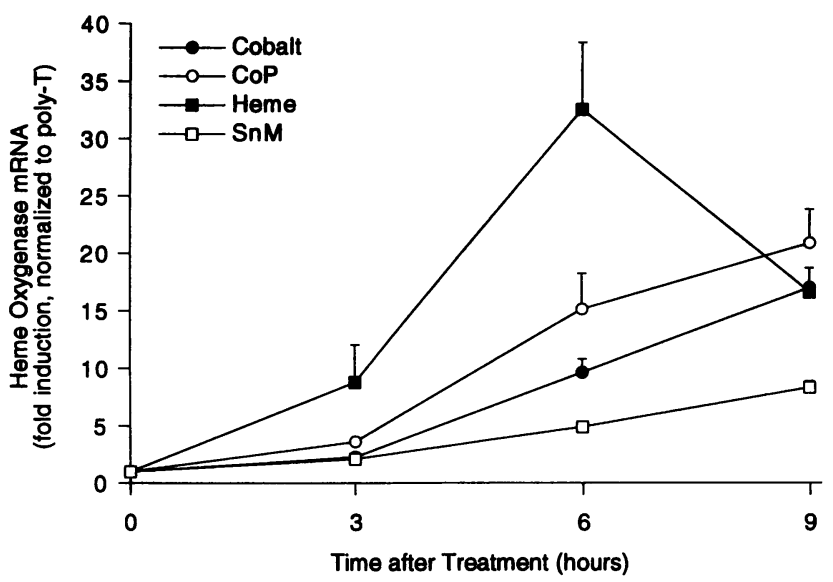

Figure 2. Temporal effects of cobalt and selected MePns on HO mRNA. Chick embryo liver cell cultures were treated with $10 \mu \mathrm{M}$ heme, CoP, SnM, or $75 \mu \mathrm{M}$ cobalt chloride for the indicated times. Cultures were harvested and samples prepared and analyzed for $\mathrm{HO}$ and poly- $\mathrm{T}$ mRNAs as described in Methods. The relative amounts of HO mRNA have been normalized as described in the legend to Fig. 1. The data represent means+SE, $n=3$; when no error bars are shown the error fell within the size of the symbol.

phyrin IX had no effect on HO mRNA (data not shown). Cobalt was used to contrast the typical metal-dependent induction of HO, with the different heme-dependent induction of HO (49).

In other experiments, addition of $\mathrm{ZnM}$ to cultures treated with heme did not affect the heme-dependent induction of HO mRNA. In the presence of $10 \mu \mathrm{M}$ heme, a concentration that induced $\mathrm{HO}$ mRNA 10 -fold after $5 \mathrm{~h}$ in culture, $10 \mu \mathrm{M} \mathrm{ZnM}$ had no effect on the level of HO mRNA. Even in the presence of $1 \mu \mathrm{M}$ heme, a concentration that induced HO mRNA threeto fourfold after $5 \mathrm{~h}, 10 \mu \mathrm{M} \mathrm{ZnM}$ did not further increase HO mRNA.

Combinations of low concentrations of $\mathrm{ZnM}$ and heme decreased ALA synthase mRNA in a dose-dependent fashion with respect to both heme and ZnM (Fig. 3). Minimal ALA synthase mRNA levels were obtained in the presence of $200 \mathrm{nM}$ heme alone, or $100 \mathrm{nM}$ heme and $>50 \mathrm{nM} \mathrm{ZnM}$ (Tukey-Kramer, $P$ $<0.05)$.

$\mathrm{ZnM}(50 \mathrm{nM})$ and heme $(200 \mathrm{nM})$, either alone or in combination, reduced the half-life of ALA synthase mRNA to the same extent as that produced by $10 \mu \mathrm{M}$ heme (Fig. 4, Table I) $(13,14)$. In contrast, SnM $(50 \mathrm{nM})$ had no effect on the halflife of ALA synthase mRNA (Table I).

\section{Discussion}

The striking overproduction of ALA and PBG in the acute porphyrias led to the suggestion that overexpression of hepatic ALA synthase was the fundamental underlying defect in all these related disorders (50). Indeed, elevated ALA synthase activity plays a key role in the pathogenesis of these disorders, as evidenced by increased urinary excretions of ALA and PBG, while reversion of ALA synthase activity to normal is associated with an asymptomatic state. Discovery of the feedback repression of heme on ALA synthase, and the development of the regulatory heme pool theory $(51,52)$ provided a sound theoretical basis for the introduction of intravenous heme as a therapy 


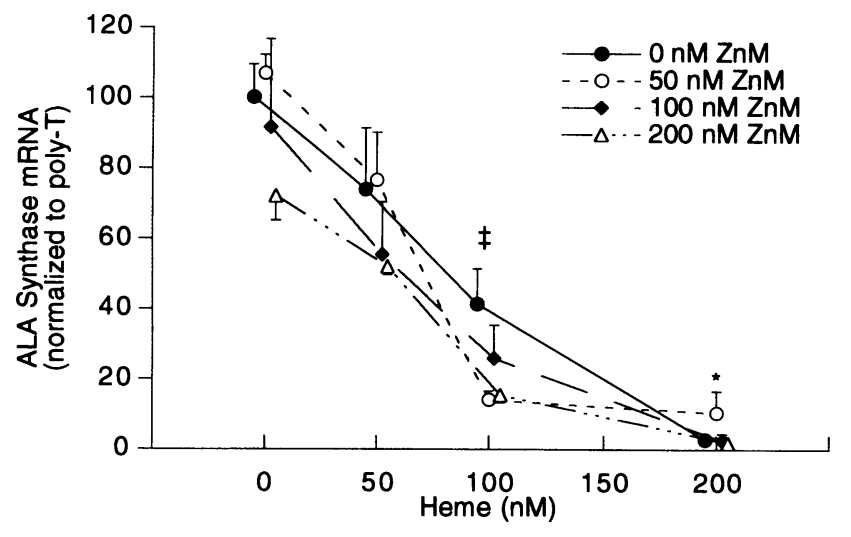

Figure 3. Effects of increasing concentrations of heme and ZnM to reduce ALA synthase mRNA. To increase ALA synthase mRNA levels, chick embryo liver cell cultures were treated with $50 \mu \mathrm{M}$ glutethimide and $50 \mu \mathrm{M}$ FeNTA for $14 \mathrm{~h}$ before addition of MePn. The cultures were exposed to the indicated concentrations of heme and/or $\mathrm{ZnM}$ for an additional $4 \mathrm{~h}$, after which they were harvested and samples prepared and analyzed as described in Methods and in the legend to Fig. 1. To improve clarity, the individual points and their error bars have been offset slightly; however, the actual concentrations of heme used were always $0,50,100$, or $200 \mathrm{nM}$. For all concentrations of heme $<200$ $\mathrm{nM}$, addition of $200 \mathrm{nM} \mathrm{ZnM}$ significantly decreased levels of the mRNA of ALA synthase, compared with $0 \mathrm{nM} \mathrm{ZnM}$. At a heme concentration of $100 \mathrm{nM}$, all concentrations of $\mathrm{ZnM}$ tested $(50,100$, and 200 $\mathrm{nM}$ ) produced significant decreases compared with $0 \mathrm{nM}$. At the heme concentration of $200 \mathrm{nM}$, no additional repressive effect of $\mathrm{ZnM}$ could be detected since levels of mRNA of ALA synthase were so markedly decreased by heme alone.

for acute porphyria (8). Heme as a negative regulator of ALA synthase activity has not only been shown experimentally ( 30 , $41,53)$. Heme has also been used clinically for the prevention of attacks of acute porphyria (54) and suppression of attacks of acute porphyria, if given early during relapse $(1-3,5,7,55$, 56). Although heme, $3-4 \mathrm{mg} / \mathrm{kg}$ per $\mathrm{d}$, is effective in treating attacks of acute porphyria, many patients so treated develop unwanted side effects (57-62). Therefore, using lower doses of heme and prolonging its duration of action would be desirable therapeutic goals.

A nonheme MePn that inhibits HO, specifically SnP, was first tested in experimental and clinical hyperbilirubinemias (18, 63), especially neonatal jaundice. Later, SnP was shown to blunt the induction of ALA synthase in a rat model of acute porphyria (17). However, in human acute porphyria, at least at the doses given $(1 \mu \mathrm{mol} / \mathrm{kg}$ per $\mathrm{d}$ for $3 \mathrm{~d}$ ), there was little, if any, evidence of a therapeutic effect of SnP alone (23). In contrast, $\mathrm{SnP}$, given with standard doses of heme $(3 \mathrm{mg} / \mathrm{kg}$ per d) to patients with acute porphyrias prolonged the duration, although it did not increase the initial effect of, heme alone (23). Cutaneous, and perhaps CNS, toxicities were complications of SnP administration (23).

Recent results from our laboratory indicate that zinc porphyrins, especially $\mathrm{ZnM}$, are as potent as $\mathrm{SnP}$ or $\mathrm{SnM}$ in decreasing activities of $\mathrm{HO}$ and ALA synthase. Indeed, for several MePns, their potencies to inhibit heme oxygenase were directly proportional to their abilities to decrease activities of ALA synthase in chick embryo liver cells in culture (30). Furthermore, low concentrations of $\mathrm{ZnM}$ and heme are additive or synergistic in decreasing activities of ALA synthase, an effect that cannot be

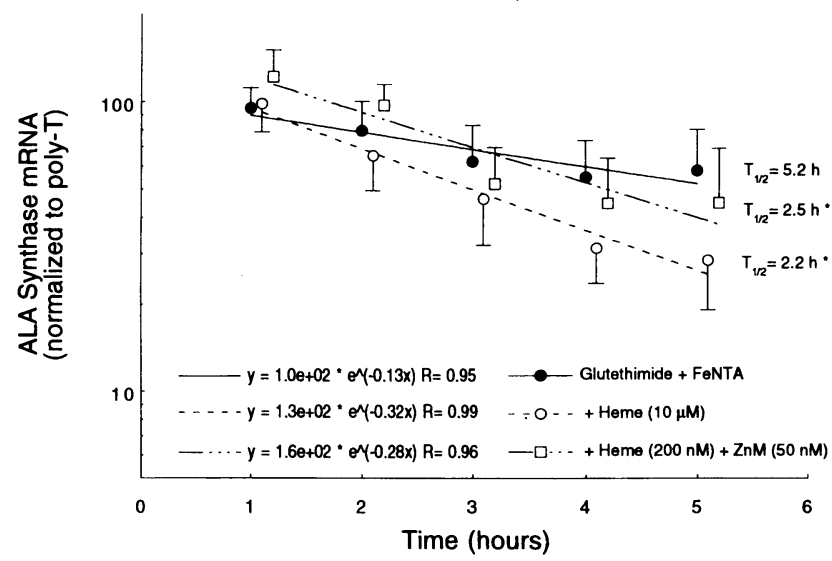

Figure 4. Effects of MePns on the half-life of ALA synthase mRNA. To increase ALA synthase mRNA levels, chick embryo liver cell cultures were treated with $50 \mu \mathrm{M}$ glutethimide and $50 \mu \mathrm{M}$ FeNTA for 14 $\mathrm{h}$ before addition of MePn. Then, $10 \mu \mathrm{M}$ heme or the combination of $200 \mathrm{nM}$ heme and $50 \mathrm{nM} \mathrm{ZnM}$ was added to the cultures for an hour, followed by addition of actinomycin $\mathrm{D}(0.4 \mu \mathrm{M})$. The cultures were harvested hourly for $5 \mathrm{~h}$ after addition of actinomycin $\mathrm{D}$ and samples prepared and analyzed as described in Methods and in the legend of Fig. 1. At each hour, the individual points and error bars have been offset slightly to improve clarity, but do not represent true differences in the times of harvest. The data represent means $+\mathrm{SE}, n=3$, and the lines shows the best exponential fits. The half-lives were calculated from the exponential decay constants. Asterisks denote significant differences from glutethimide + FeNTA, MANOVA.

attributed to direct inhibition of the synthase $(30,41)$. However, an unwanted effect of some nonheme MePns, including tinporphyrins, is the induction of $\mathrm{HO} \mathrm{mRNA}$ and protein $(25$, 26). These inductive effects may tend to counterbalance their

Table I. Effects of MePns on the Half-Life of ALA Synthase mRNA

\begin{tabular}{lcc}
\hline \multicolumn{1}{c}{ Treatment } & & $\begin{array}{c}\text { Exponential } \\
\text { decay constants } \\
k \pm \mathrm{SE}\end{array}$ \\
\hline & Half-life & \\
Glutethimide + FeNTA & 5.2 & $0.13 \pm 0.03$ \\
$+10 \mu \mathrm{M}$ heme & 2.2 & $0.32 \pm 0.03^{*}$ \\
+ ZnM $(50 \mathrm{nM})+$ heme $(200 \mathrm{nM})$ & 2.5 & $0.28 \pm 0.06^{*}$ \\
+ ZnM $(50 \mathrm{nM})$ & 1.8 & $0.38 \pm 0.06^{*}$ \\
+ Heme $(200 \mathrm{nM})$ & 2.5 & $0.28 \pm 0.06^{*}$ \\
+ SnM $(50 \mathrm{nM})$ & 5.4 & $0.13 \pm 0.08$
\end{tabular}

To increase ALA synthase mRNA levels, chick embryo liver cell cultures were treated with $50 \mu \mathrm{M}$ glutethimide and $50 \mu \mathrm{M}$ FeNTA for 14 $\mathrm{h}$ before addition of MePn. The indicated MePns were then added to the cultures followed by addition of actinomycin D $(0.4 \mu \mathrm{M})$ at $15 \mathrm{~h}$ after initial treatment. The cultures were harvested and samples prepared and analyzed as described in Methods and in the legend of Fig. 1. The data represent means \pm SE, $n=3$. The exponential decay constants and the standard errors of the best fit lines are shown in the last column. An asterisk represents a significant increase in the decay constant versus glutethimide + FeNTA alone (Student's $t$ test modified for testing regressions in two populations, $P<0.05$ ). The half-lives are calculated from the equation: $t_{1 / 2}=\ln 2 / k$. 
inhibitory effects on HO activity. Depending upon the relative time courses of, and doses needed for, these opposing effects, the net outcome of administration of nonheme MePns may be to decrease or to increase activity of $\mathrm{HO}$ and may change over time. Indeed, induction of the mRNA and protein for HO by SnP may in part account for its modest effect on hyperbilirubinemia or acute porphyria.

Since in previous work all the MePns that were effective at inhibiting $\mathrm{HO}$ also increased protein or mRNA levels of the oxygenase $(25,26)$, one might expect that every nonheme $\mathrm{MePn}$, inhibitory for $\mathrm{HO}$ activity, would also induce $\mathrm{HO}$ mRNA. While it is not unexpected that some MePns (e.g., MnP [Fig. 1]) have no effect on ALA synthase, the discovery that $\mathrm{ZnM}$ is as effective at reducing ALA synthase mRNA as heme or SnM, but without affecting HO mRNA (Fig. 1), is a novel and important finding in this work.

The data presented here, and in previous work (30), suggest that a combination of $\mathrm{ZnM}$ and heme may be a useful therapeutic regimen for the management of acute porphyria. The low doses $(50 \mathrm{nM})$ at which $\mathrm{ZnM}$ exerts an effect on both ALA synthase mRNA and activity (Fig. 3, references 30,41) are at least one order of magnitude lower than concentrations of MePns previously reported to be effective. Other data from Vreman et al. (27) have described ZnM as an ineffective catalyst of the photodegradation of tryptophan and other organic molecules in vitro. In vivo phototoxicity studies demonstrated a high mortality in rats given SnP at $11.7 \mu \mathrm{mol} / \mathrm{kg}$ or SnM at $30 \mu \mathrm{mol} /$ $\mathrm{kg}$, while $\mathrm{ZnP}$ or $\mathrm{ZnM}$ did not produce any mortality at 40 $\mu \mathrm{mol} / \mathrm{kg}$ (31). Taken together, these data suggest that $\mathrm{ZnM}$ is at least as potent as, and has fewer side effects than, the tinporphyrins currently in investigational human use.

The effects of heme and nonheme MePns on ALA synthase mRNA provide a biochemical explanation for the potency of $\mathrm{ZnM}$ and heme at reducing ALA synthase activity (Fig. 1, references 30,41$)$. ZnM (50 $\mathrm{nM})$ and heme (200 $\mathrm{nM})$, alone or in combination, were just as effective at reducing the stability of ALA synthase mRNA as $10 \mu \mathrm{M}$ heme (Fig. 4, Table I) (13, 14). The quantitative relationship between an observed steady state level of ALA synthase mRNA and the half-life of the mRNA remains to be elucidated. The inability of SnM (50 nM) to change the half-life of ALA synthase mRNA reflects the inability of this concentration of SnM to affect steady state levels of ALA synthase (30). There may be other effects of nonheme MePns on ALA synthase, such as on the mitochondrial processing and import of the enzyme $(15,16)$. Additional studies exploring these possibilities are currently underway.

In summary, the rationale for using a combination of heme and a MePn inhibitory for HO is supported not only by the clinical findings of Dover et al. (23) but also by the work described in this paper. The ability of nonheme MePns to enhance the effectiveness of heme may have therapeutic potential for not only acute porphyrias but also other porphyrias and other disorders in which heme appears to have therapeutic potential $(5,64-67)$. The studies described here, in light of other recent results from our $(30,41)$ and other $(27,31)$ laboratories, provide a solid experimental basis for studies of low dose heme and $\mathrm{ZnM}$ for acute porphyria and perhaps other disorders as well.

\section{Acknowledgments}

We thank J. D. Engel (Northwestern University, Evanston, IL) for the gift of the plasmid, pALX (42), and D. Thayer for help with typing the manuscript.
This study was supported by the following grants from the National Institutes of Health: DK-38825 (to H. L. Bonkovsky) and P41RR06009 (to Pittsburgh Supercomputing Center).

\section{References}

1. Kappas, A., S. Sassa, R. A. Galbraith, and Y. Nordmann. 1989. The porphyrias. In The Metabolic Basis of Inherited Disease. 6th ed. C. R. Scriver, A. L. Beaudet, W. S. Sly, and D. Valle, editors. McGraw-Hill Inc., New York. 13051365.

2. Bonkovsky, H. L. 1990. Porphyrin and heme metabolism and the porphyrias. In Hepatology: A Textbook of Liver Disease. 2nd ed. D. Zakim and T. D. Boyer editors. W. B. Saunders Company, Philadelphia. 378-424.

3. Bonkovsky, H. L. 1993. Advances in understanding and treating 'the little imitator,' acute porphyria. Gastroenterol. 105:590-594.

4. Grinstein, M., R. A. Aldrich, V. Hawkinson, and C. J. Watson. 1949. An isotopic study of porphyrin and haemoglobin metabolism in a case of porphyria J. Biol. Chem. 179:983-984.

5. Mustajoki, P., R. Tenhunen, C. Pierach, and L. Volin. 1989. Heme in the treatment of porphyrias and hematological disorders. Semin. Hematol. 26:1-9.

6. Tenhunen, R., O. Tokola, and I.-B. Lindén. 1987. Haem arginate: a new stable haem compound. J. Pharm. Pharmacol. 39:780-786.

7. Mustajoki, P., R. Tenhunen, O. Tokola, and G. Gothoni. 1986. Haem arginate in the treatment of acute hepatic porphyrias. Br. Med. J. Clin. Res. 293:538-539.

8. Bonkowsky, H. L., D. P. Tschudy, A. Collins, J. Doherty, I. Bossenmaier, R Cardinal, and C. J. Watson. 1971. Repression of the overproduction of porphyrin precursors in acute intermittent porphyria by intravenous infusions of hematin. Proc. Natl. Acad. Sci. USA. 68:2725-2729.

9. Srivastava, G., J. D. Brooker, B. K. May, and W. H. Elliott. 1980. Haem control in experimental porphyria. The effect of haemin on the induction of $\delta$ aminolaevulinate synthase in isolated chick-embryo liver cells. Biochem. J. 188:781-788.

10. May, B. K., and M. J. Bawden. 1989. Control of heme biosynthesis in animals. Semin. Hematol. 26:150-156.

11. Tokola, O., I.-B. Linden, and R. Tenhunen. 1987. The effects of haem arginate and haematin upon the allylisopropylacetimide induced experimental porphyria in rats. Pharmacol. \& Toxicol. 61:75-78.

12. Schoenfeld, N., A. J. Wysenbeek, Y. Greenblat, O. Epstein, A. Atsmon, and D. P. Tschudy. 1984. The effects of metalloporphyrins, porphyrins and metals on the activity of $\delta$-aminolevulinic acid synthase in monolayers of chick embryo liver cells. Biochem. Pharmacol. 33:2783-2788.

13. Hamilton, J. W., W. J. Bement, P. R. Sinclair, J. F. Sinclair, J. A. Alcedo, and K. E. Wetterhahn. 1991. Heme regulates hepatic 5-aminolevulinate synthase mRNA expression by decreasing mRNA half-life and not by altering its rate of transcription. Arch. Biochem. Biophys. 289:387-392.

14. Drew, P. D., and I. Z. Ades. 1989. Regulation of the stability of chicken embryo liver $\delta$-aminolevulinate synthase mRNA by hemin. Biochem. Biophys. Res. Commun. 162:102-107.

15. Ades, I. Z., and K. G. Harpe. 1981. Biogenesis of mitochondrial proteins. Identification of the mature and precursor forms of the subunit of $\delta$-aminolevulinate synthase from embryonic chick liver. J. Biol. Chem. 256:9329-9333.

16. Lathrop, J. T., and M. P. Timko. 1993. Regulation of heme mitochondrial protein transport through a conserved amino acid motif. Science (Wash. DC). 259:522-525.

17. Galbraith, R. A., G. S. Drummond, and A. Kappas. 1985. Sn-protoporphyrin supresses chemically induced experimental hepatic porphyria. J. Clin. Invest. 76:2436-2439.

18. Drummond, G. S., and A. Kappas. 1981. Prevention of neonatal hyperbilirubinemia by tin protoporphyrin IX, a potent competitive inhibitor of heme oxidation. Proc. Natl. Acad. Sci. USA. 78:6466-6470.

19. Drummond, G. S., and A. Kappas. 1982. Chemoprevention of neonatal jaundice: potency of tin-protoporphyrin in an animal model. Science (Wash. DC). 217:1250-1252.

20. Drummond, G. S., R. A. Galbraith, M. K. Sardana, and A. Kappas. 1987. Reduction of the C2 and C4 vinyl groups of Sn-protoporphyrin to form Snmesoporphyrin markedly enhances the ability of the metalloporphyrin to inhibit in vivo heme catabolism. Arch. Biochem. Biophys. 255:64-74.

21. Drummond, G. S., N. L. Greenbaum, and A. Kappas. 1991. Tin $\left(\mathrm{Sn}^{+4}\right)-$ diiododeuteroporphyrin: an in vitro and in vivo inhibitor of heme oxygenase with substantially reduced photoactive properties. J. Pharm. Exp. Ther. 257:11091113.

22. Land, E. J., A. F. McDonagh, D. J. McGarvey, and T. G. Truscott. 1988. Photophysical studies of tin(IV)-protoporphyrin: potential phototoxicity of a chemotherapeutic agent proposed for the prevention of neonatal jaundice. Proc. Natl. Acad. Sci. USA. 85:5249-5253.

23. Dover, S. B., M. R. Moore, E. J. Fitzsimons, A. Graham, and K. E. L. McColl. 1993. Tin-protoporphyrin prolongs the biochemical remission produced by heme arginate in acute hepatic porphyria. Gastroenterol. 105:500-506. 
24. Mark, J. A., and M. D. Maines. 1992. Tin-protoporphyrin-mediated disruption in vivo of heme oxygenase- 2 protein integrity and activity in rat brain. Pediatr. Res. 32:324-329.

25. Sardana, M. K., and A. Kappas. 1987. Dual control mechanism for heme oxygenase: tin(IV)-protoporphyrin potently inhibits enzyme activity while markedly increasing content of enzyme protein in liver. Proc. Natl. Acad. Sci. USA. 84:2464-2468.

26. Smith, A., J. Alam, P. V. Escriba, and W. T. Morgan. 1993. Regulation of heme oxygenase and metallothionein gene expression by the heme analogs, cobalt-, and tin-protoporphyrin. J. Biol. Chem. 268:7365-7371.

27. Vreman, H. J., B. C. Ekstrand, and D. K. Stevenson. 1993. Selection of metalloporphyrin heme oxygenase inhibitors based on potency and photoreactivity. Pediatr. Res. 33:195-200.

28. Vreman, H. J., O. K. Lee, and D. K. Stevenson. 1991. In vitro and in vivo characteristics of a heme oxygenase inhibitor: ZnBG. Am. J. Med. Sci. 302:335341 .

29. Vreman, H. J., S. R. Hintz, C. B. Kim, R. O. Castillo, and D. K. Stevenson. 1988. Effects of oral administration of tin and zinc protoporphyrin on neonatal and adult rat tissue heme oxygenase activity. J. Ped. Gastroenterol. Nutr. 7:902906.

30. Cable, E. E., J. W. Cable, and H. L. Bonkovsky. 1993. Repression of hepatic $\delta$-aminolevulinate synthase by heme and metalloporphyrins: relationship to inhibition of heme oxygenase. Hepatology. 18:119-127.

31. Hintz, S. R., H. J. Vreman, and D. K. Stevenson. 1990. Mortality of metalloporphyrin-treated neonatal rats after light exposure. Dev. Pharm. Ther. 14:187-192.

32. Lamola, A. A., and T. Yamane. 1974. Zinc protoporphyrin in the erythrocytes of patients with lead intoxication and iron deficiency anemia. Science (Wash. DC). 186:936-938.

33. Lamola, A. A., S. Piomelli, M. G. Poh-Fitzpatrick, T. Yamane, and L. C. Harber. 1975. Erythropoietic protoporphyria and lead intoxication: the molecular basis for difference in cutaneous photosensitivity. II. Different binding of erythrocyte protoporphyrin to hemoglobin. J. Clin. Invest. 56:1528-1535.

34. Sassa, S., and S. Granick. 1970. Induction of $\delta$-aminolevulinic acid synthase in chick embryo liver cells in culture. Proc. Natl. Acad. Sci. USA. 67:517522.

35. Shedlofsky, S. I., H. L. Bonkovsky, P. R. Sinclair, J. F. Sinclair, and W. J. Bement. 1982. Iron loading of cultured hepatocytes accelerates heme breakdown and enhances $\delta$-aminolevulenic acid synthase (ALAS) induction. Hepatology. 2:732.

36. Cable, E. E., J. F. Healey, Y. Greene, C. O. Evans, and H. L. Bonkovsky. 1991. Synergistic induction of $\delta$-aminolevulinate synthase by glutethimide and iron: relationship to the synergistic induction of heme oxygenase. Biochim. Biophys. Acta. 1080:245-251.

37. Cable, E., Y. Greene, J. Healey, C. O. Evans, and H. Bonkovsky. 1990. Mechanism of synergistic induction of hepatic heme oxygenase by glutethimide and iron: studies in cultured chick embryo liver cells. Biochem. Biophys. Res. Commun. 168:176-181.

38. Bonkovsky, H. L., J. F. Healey, P. R. Sinclair, and J. F. Sinclair. 1985. Conversion of 5-aminolevulinate into heme by homogenates of human liver: comparison with rat and chick liver homogenates. Biochem. J. 227:893-901.

39. Healey, J. F., H. L. Bonkovsky, P. R. Sinclair, and J. F. Sinclair. 1981. Conversion of 5-aminolevulinate into heme by liver homogenates: comparison of rat and chick embryos. Biochem. J. 198:595-604.

40. Bonkovsky, H. L., J. F. Healey, A. N. Lourie, and G. G. Gerron. 1991. Intravenous heme-albumin in acute intermittent porphyria: evidence for repletion of hepatic hemoproteins and regulatory heme pools. Am. J. Gastroenterol. 86:1050-1056.

41. Russo, S., J. Pepe, J. Cable, and H. Bonkovsky. 1993. Synergism of heme and zinc mesoporphyrin to repress hepatic 5-aminolevulinate synthase: studies in a cell culture model of acute porphyria. Gastroenterol. 104:A982. (Abstr.)

42. Dover, S. B., A. Graham, E. Fitzsimons, M. R. Moore, and K. E. L. McColl. 1991. Haem-arginate plus tin-protoporphyrin for acute hepatic porphyria. Lancet. 338:263.

43. Falk, J. E. 1964. Porphyrins and metalloporphyrins. Elsevier Science Publishing Co., Inc., New York. 242-246.

44. Riddle, R. D., M. Yamamoto, and J. D. Engel. 1989. Expression of $\delta$ aminolevulinate synthase in avian cells: separate genes encode erythroid-specific and nonspecific isozymes. Proc. Natl. Acad. Sci. USA. 86:792-796.

45. Srivastava, K. K., E. E. Cable, S. E. Donohue, and H. L. Bonkovsky. 1993. Molecular basis for heme-dependent induction of heme oxygenase in normal hepatocytes with demonstration of aquired refractoriness to heme. Eur. J. Biochem. 213:909-917.

46. Bonkovsky, H. L., E. E. Cable, J. W. Cable, S. E. Donohue, E. C. White, Y. J. Greene, R. W. Lambrecht, K. K. Srivastava, and W. N. Arnold. 1992. Porphyrogenic properties of camphor, pinene, and thujone (with a note on historic implications for absinthe and the illness of Vincent van Gogh). Biochem. Pharmacol. 43:2359-2368.

47. Hollander, M. C., and A. J. Fornace, Jr. 1990. Estimation of relative mRNA content by filter hybridization to a polythymidylate probe. Biotechniques. 9:174-179.

48. Cable, E. E. 1993. Regulation of $\delta$-aminolevulinic acid synthase and heme oxygenase in cultured chick embryo liver cells: synergistic induction of both enzymes by glutethimide and iron and repression of $\delta$-aminolevulinic acid synthase by metalloporphyrins and heme. Ph.D. thesis. University of Massachusetts Medical Center, Lamar Soutter Library, Worcester, MA. 340 pp.

49. Lincoln, B. C., J. F. Healey, and H. L. Bonkovsky. 1988. Regulation of hepatic haem metabolism. Disparate mechanisms of induction of haem oxygenase by drugs and metals. Biochem. J. 250:189-196.

50. Tschudy, D. P., M. G. Perlroth, H. S. Marver, A. Collins, G. Hunter, Jr. and M. Rechcigl, Jr. 1965. Acute intermittent porphyria: the first "overproduction disease" localized to a specific enzyme. Proc. Natl. Acad. Sci. USA. 53:841847.

51. Granick, S., P. R. Sinclair, S. Sassa, and G. Grieninger. 1975. Effects by heme, insulin and serum albumin on heme and protein synthesis in chick embryo liver cells cultured in a chemically defined medium, and a spectrofluorometric assay for porphyrin composition. J. Biol. Chem. 250:9215-9225.

52. Granick, S. 1966. The induction in vitro of the synthesis of $\delta$-aminolevulinic acid synthetase in chemical porphyria: a response to certain drugs, sex hormones, and foreign chemicals. J. Biol. Chem. 241:1359-1375.

53. Sinclair, P. R., and S. Granick. 1975. Heme control on the synthesis of $\delta$-aminolevulinic acid synthetase in cultured chick embryo liver cells. Ann. N. Y Acad. Sci. 244:509-520.

54. Lamon, J. M., B. C. Frykholm, M. Bennett, and D. P. Tschudy. 1978. Prevention of acute porphyric attacks by intravenous haematin. Lancet (N. Am. Ed.). 2:492-494.

55. Lamon, J. M., B. C. Frykholm, R. A. Hess, and D. P. Tschudy. 1979. Hematin therapy for acute porphyria. Medicine (Baltimore). 58:252-269.

56. Mustajoki, P., and Y. Nordmann. 1993. Early administration of heme arginate for acute porphyric attacks. Arch. Intern. Med. 153:2004-2008.

57. Simionatto, C. S., R. Cabal, R. L. Jones, and R. A. Galbraith. 1988 Thrombophlebitis and disturbed hemostasis following administration of intravenous hematin in normal volunteers. Am. J. Med. 85:538-540.

58. Goetsch, C. A., and D. M. Bissell. 1986. Instability of hematin used in the treatment of hepatic porphyria. N. Engl. J. Med. 315:235-238.

59. Morris, D. L., M. D. Dudley, and R. D. Pearson. 1981. Coagulopathy associated with hematin treatment for acute intermittent porphyria. Ann. Intern. Med. 95:700-701.

60. Petersen, J. M., and C. A. Pierach. 1984. Hematin induced hemolysis in acute porphyria. Ann. Intern. Med. 101:877.

61. Dhar, G. J., I. Bossenmaier, R. Cardinal, Z. J. Petryka, and C. J. Watson. 1978. Transitory renal failure following rapid administration of a relatively large amount of hematin in a patient with acute intermittent porphyria in clinical remission. Acta Med. Scand. 203:437-443.

62. Khanderia, U. 1986. Circulatory collapse associated with hemin therapy for acute intermittent porphyria. Clin. Pharm. 5:690-692.

63. Drummond, G. S., and A. Kappas. 1986. Sn-protoporphyrin inhibition of fetal and neonatal brain heme oxygenase. Transplacental passage of the metalloporphyrin and prenatal suppression of hyperbilirubinemia in the newborn animal. J. Clin. Invest. 77:971-976.

64. Abraham, N. G., J. L. Chertkov, R. Staudinger, S. Jiang, J. D. Lutton, I. Argani, R. D. Levere, and A. Kappas. 1993. Long-term bone marrow stromal and hemopoietic toxicity to AZT: protective role of heme and IL-1. Exp. Hematol. (NY). 21:263-268.

65. Levere, R. D., Y. F. Gong, A. Kappas, D. J. Bucher, G. P. Wormser, and N. G. Abraham. 1991. Heme inhibits HIV-1 replication in cell cultures and enhances the anti-viral effect of zidovudine. Proc. Natl. Acad. Sci. USA. 88:1756.

66. Levere, R. D., P. Martasek, B. Escalante, M. L. Schwartzman, and N. G. Abraham. 1990. Effect of heme arginate administration on blood pressure in spontaneously hypertensive rats. J. Clin. Invest. 86:213-219.

67. Volin, L. 1989. Haem arginate treatment for hereditary sideroblastic anaemia. Eur. J. Haematol. 42:60-66. 